\title{
Physicochemical Properties and Sensory Score of Press Ham Made from Chicken Fed with Citrus Byproduct
}

Yoon-Hee Moon and In-Chul Jung ${ }^{1}$ *

Dept. of Food Science and Biotechnology, Kyungsung University, Busan 608-736, Korea

${ }^{1}$ Div. of Food Beverage and Culinary Arts, Daegu Technical University, Daegu 704721, Korea

Received October 7, 2009 /Accepted December 14, 2009

\begin{abstract}
In this study, the physicochemical and sensory characteristics of chicken press ham not fed with citrus byproduct (T0) and fed with citrus byproduct (T1) were compared. There was not a significant difference in moisture, crude protein, crude fat, crude ash, crude fiber, Hunter's L* (lightness), a (redness), b (yellowness), hardness, springiness, cohesiveness, gumminess, chewiness, shear force, water holding capacity and $\mathrm{pH}$ between $\mathrm{T} 0$ and $\mathrm{T} 1$. There was not a significant difference between $\mathrm{T} 0$ and $\mathrm{T} 1$ in terms of the chicken ham's VBN (volatile basic nitrogen) content for the first three weeks of storage, but after the fourth week of storage, the VBN content was 15.1 and $13.7 \mathrm{mg} \%$ for T0 and T1, respectively, which implies that feeding citrus byproduct significantly reduced the VBN content. There was not a significant difference between T0 and T1 in terms of the chicken press ham's TBARS (2-thiobarbituric acid reactive substances) value for the first two weeks of storage. However, the TBARS value was 0.31 and $0.22 \mathrm{mg}$ malonaldehyde/ $\mathrm{kg}$ for T0 and T1 during the third week of storage, and 0.49 and 0.32 $\mathrm{mg}$ malonaldehyde/ $\mathrm{kg}$ for $\mathrm{T} 0$ and $\mathrm{T} 1$ during the fourth week of storage. There was not a significant difference between T0 and T1 in terms of the chicken press ham's TPC (total plate counts) for the first three weeks of storage, but after the fourth week of storage, the TPC was 4.96 and $4.72 \mathrm{log}$ CFU/g for T0 and T1, respectively, which implies that T1 showed a significantly lower TPC than T0. T1 showed significantly higher aroma, taste, and palatability of the chicken press ham than T0, but there was a not significant difference in texture and juiciness between $\mathrm{T} 0$ and $\mathrm{T} 1$.
\end{abstract}

Key words : Chicken press ham, citrus byproduct, physicochemical properties, sensory

\section{서 론}

우리나라는 고령화 사회에 접어들면서 노인인구가 증가하 고, 과거보다 식생활 수준이 향상되면서 영양과 건강에 대한 관심이 높다. 최근의 식품소비는 건강유지나 향상을 위주로 이루어지고 있으며, 식품업계에서는 인체에 유해한 원재료나 식품첨가물의 사용을 스스로 제한하고 있다. 식육제품의 경우 저장성, 품질유지, 기호도 향상 등을 위하여 보존료로서 sorbic acid를 사용하여 왔고[12], 항산화제로서 BHA, BHT, propyl gallate 등을 사용하였으며[10,11], 색깔의 보존을 위하여 발색 제인 질산염 및 아질산염을 사용하였다[25]. 그러나 이들 식품 첨가물들이 돌연변이, 발암물질 형성 등 식품의 안전성에 유 해한 것으로 알려지면서[6], 인체에 대한 저해요소를 방지하거 나 최소화하기 위하여 법적으로 사용량을 제한하고 있다[9]. 그러나 합성식품첨가물들의 사용을 법적 기준치 이하로 사용 하고 있지만 소비자들은 이들의 사용에 대하여 민감하다. 따 라서 학계나 업계에서는 이들을 대체할 수 있는 방법을 찾기 위한 연구가 꾸준히 진행되어 왔다.

*Corresponding author

Tel : +82-53-560-3854, Fax : +82-53-560-3869

E-mail : inchul3854@hanmail.net
식육제품에 천연물질을 첨가하여 저장성, 품질유지, 기호 도 향상 등에 관한 연구동향 몇 가지를 보면 Georgantelis 등 [3]은 우육 햄버거를 제조할 때 로즈마리와 키토산을 혼합하 여 첨가하면 항산화 효과가 크고 제품의 적색도 유지기간이 연장되었다고 하였으며, Mytle 등[13]은 닭고기 소시지에 클 로버 오일을 첨가하였을 경우 항균성이 있다고 하였고, Sallam 등[18]은 닭고기 소시지에 마늘을 첨가하였을 경우 항 산화작용과 항균작용이 있다고 하였다. 국내에서도 식육제품 에 천연물질을 첨가한 다양한 연구가 이루어졌는데 Jung 등 [4]은 깻잎분말을 돈육소시지 제조에 첨가하여 품질 및 기호 성에 미치는 영향을 연구하였으며, Nam 등[14]은 돈육 patty 에 쑥, 솔잎, 두릅 추출물을 첨가하여 품질특성을 규명하여 하였다. 그리고 $\mathrm{Kim}$ 등[8]은 울금 추출물을 저지방 소시지에 첨가하여 저장 중 품질특성을 연구하였으며, Park과 Chin [17]은 복분자 추출물을 돈육 patty에 첨가하여 항산화 능력 을 연구하였다. 이와 같이 식육제품에 천연의 물질들을 그대 로 또는 추출하여 첨가하는 연구들은 많이 이루어졌지만 천 연의 물질을 사료에 첨가하여 사육하고 그것을 식육제품으로 제조하여 제품의 저장성이나 품질특성을 연구한 것은 거의 없는 실정이다. 특히 감귤주스 제조 후 남는 부산물을 급여하 여 닭고기의 품질을 연구한 것은 찾아볼 수 있지만[24] 그것 
을 이용하여 식육제품을 제조하여 연구한 것은 없었다. 한편 감귤부산물은 hesperidin, naringin 등의 flavonoid류가 많이 함유되어 있어서 항균, 항산화, 항돌연변이, 항염증, 항알러 지, 항바이러스 작용이 있고, 순환기계질병 예방, 모세혈관 강 화 등의 효과가 있는 것으로 알려져 있다[16]. 이러한 유효성 분을 이용하여 가축을 사육하고, 그 고기를 이용하여 식육제 품을 제조하여 저장성 및 품질특성을 밝히는 것은 페기물의 이용과 안전한 식육제품 제조라는 측면에서 소비자들의 관심 을 끌기에 충분하다. 따라서 본 연구는 닭에게 감귤부산물을 급여하여 얻어진 고기를 프레스 햄 제조에 이용하고 품질특 성, 저장성 및 기호성을 검토하였다.

\section{재료 및 방법}

\section{공시재료 및 프레스 햄 제조}

닭고기(Rose종)는 감귤부산물을 첨가하지 않고 사육한 육 계(T0)와 초기(1 9일), 중기(10 24일) 및 후기(25 36일) 사 료에 감귤부산물을 각각 $1.0,1.5$ 및 $2.0 \%$ 첨가하여 사육한 육 계(T1)를 제주도 육계조합 도계장에서 공급받았다. 공급받은 닭의 가슴살과 다리살은 $8 \mathrm{~mm}$, 돼지지방은 $5 \mathrm{~mm}$ 로 마쇄 (WD, Germany)하였다. 닭고기 프레스 햄을 제조하기 위한 원부재료는 Table 1 과 같다. 염지액은 물에 난백분말, 분리대 두단백, 소금, 아질산나트륨, 폴리인산나트륨, seasoning 분말, 설탕, 코치닐 추출색소, 아스콜빈산, 자몽종자 추출물, 불갈비 맛 엑기스 등을 혼합교반하여 제조하였으며, 염지는 $0 \sim 5^{\circ} \mathrm{C}$ 에 서 48 시간하였다. 염지가 완료된 염지육을 vacuum mixer (VM300, Spain)에 넣고 회전하면서 20분간 배합하고, 포장 단 위별로 충진(VF-80, Germany)하여, 훈연실(ARS-RONDAIR 012, Germany)에서 가열처리하였다. 그리고 흐르는 물에 씻 은 후 냉각하고 $4^{\circ} \mathrm{C}$ 의 냉장실에 저장하면서 실험하였다.

\section{일반성분}

닭고기 프레스 햄의 수분, 조단백, 조지방, 조회분 및 조섬유 함량은 식품공전[9]의 방법에 준하여 실험하였다.

\section{표면색도}

표면색도는 색차계(Chromameter CR-200b, Minolta Camera Co., Japan)를 이용하여 명도(lightness, L"값), 적색도(redness, $a^{*}$ 값) 및 황색도(yellowness, $b^{*}$ 값)를 측정하였다. 이 때 색보정 을 위하여 사용된 calibration plate의 $\mathrm{L}^{*}, \mathrm{a}^{*}$ 및 $\mathrm{b}^{*}$ 값은 각각 $97.5,-6.1$ 및 7.4 이었다.

\section{기계적 조직감}

기계적 조직감은 근섬유와 평행하게 가로, 세로, 높이를 각 각 40, 15 및 $5 \mathrm{~mm}$ 로 자르고 rheometer (CR-200D, SUN Scientific Co., Japan)를 이용하여 측정하였다. 이때 경도
Table 1. Composition of chicken press ham materials $(\mathrm{kg})$

\begin{tabular}{lc}
\hline \multicolumn{1}{c}{ Materials } & Composition \\
\hline Chicken breast muscle & 25.00 \\
Chicken thigh muscle & 30.00 \\
Pork fat & 15.00 \\
Ice water & 24.00 \\
Isosoy protein (ISP 500E) & 1.00 \\
Egg albumin & 2.00 \\
Sodium chloride & 1.00 \\
Sodium nitrate (NPS, 6.25\%) & 0.20 \\
Sodium polyphosphate & 0.25 \\
Taste seasoning powder & 0.40 \\
Sugar & 0.50 \\
Red powder N (\#1267) & 0.05 \\
Chicken seasoning powder & 1.00 \\
Beef extract paste & 1.50 \\
Ascorbate & 0.05 \\
Pomelo extract (DF-100) & 0.05 \\
Wheat starch & 3.00 \\
Carrageenan & 0.50 \\
Meat base RG & 0.10 \\
\hline
\end{tabular}

(hardness), 탄성(springiness), 응집성(cohesiveness)은 round adapter 25번을 이용하여 table speed $120 \mathrm{~mm} / \mathrm{min}$, graph interval $30 \mathrm{~m} / \mathrm{sec}$, load cell (Max) $2 \mathrm{~kg}$ 의 조건으로 측정하였 다. 뭉침성(gumminess)은 peak max $\times$ cohesiveness값으로, 씹 힘성(chewiness)은 (peak $\max \div$ distance) $\times$ cohesiveness $\times$ springiness값으로 나타내었다.

\section{$\mathrm{pH}, \mathrm{VBN}$ 함량, TBARS값 및 총균수}

프레스 햄의 $\mathrm{pH}$ 측정은 대기온도에서 $\mathrm{pH} 4.00$ 과 $7.00 \mathrm{buffer}$ 로 보정한 유리전극이 부착된 $\mathrm{pH}$ meter (ATI Orion 370, USA) 를 이용하여 측정하였는데, 시료는 분쇄한 후 $10 \mathrm{~g}$ 을 취하여 증류수 $40 \mathrm{ml}$ 와 함께 균질한 후 측정하였다. $\mathrm{VBN}$ 함량은 식품 공전[9]에 준하여 실험하였다. 그리고 TBARS (2-thiobarbituric acid reactive substances) 값은 시료 $2 \mathrm{~g}$ 을 perchloric acid 18 $\mathrm{ml}$ 및 BHT $50 \mu \mathrm{l}$ 와 함께 균질하고 여과하여 얻어진 여과액 $2 \mathrm{ml}$ 에 2-thiobarbituric acid $2 \mathrm{ml}$ 를 가하고 $531 \mathrm{~nm}$ 에서 흡광 도를 측정하여 나타난 값을 시료 $\mathrm{kg}$ 당 반응물 $\mathrm{mg}$ malonaldehyde로 계산하였다[1]. 총균수는 total plate count agar를 이 용한 표준평판법으로 $37 \pm 1^{\circ} \mathrm{C}$ 에서 48 시간 동안 배양한 다음 균수를 계측하였다[9].

\section{관능검사 및 통계처리}

관능검사는 훈련된 관능평가원 10 명이 2 회에 걸쳐 의하여 맛, 풍미, 연도, 다즙성 및 전체적인 기호도에 대하여 가장 좋 다(like extremely)를 7점, 가장 나쁘다(dislike extremely)를 1 점으로 하는 7점 기호척도법으로 하였다[22]. 그리고 얻어진 결과의 자료들은 SPSS program [21]을 이용하여 분석하고 
Duncan's multiple range test로 5\% 수준에서 유의성을 검정 하였다.

\section{결과 및 고찰}

\section{닭고기 프레스 햄의 일반성분}

감귤부산물을 급여하지 않은 닭고기로 제조한 프레스 햄 (T0)과 감귤부산물을 급여한 닭고기로 제조한 프레스 햄(T1) 의 일반성분 함량은 Table 2 와 같다. 수분함량은 $\mathrm{T} 0$ 및 $\mathrm{T} 1$ 이 각각 $54.1 \%$ 및 $53.8 \%$, 조단백질 각각 $25.3 \%$ 및 $25.0 \%$, 조지방 각각 $15.8 \%$ 및 $16.2 \%$, 조회분은 각각 $4.7 \%$ 및 $4.6 \%$ 그리고 조섬유는 각각 0.1 및 $0.4 \%$ 로 감귤부산물 급여의 영향이 없었 다. 육제품의 일반성분은 원료 첨가비율에 의하여 결정되기 때문에[20] 본 연구의 일반성분들이 두 시료 사이에 차이가 없는 것은 프레스 햄을 제조할 때에 같은 양의 살코기, 지방, 물, 기타 첨가물들을 사용했기 때문인 것으로 평가된다.

\section{닭고기 프레스 햄의 표면색도}

닭고기로 제조한 프레스 햄의 표면색도를 Table 3에 나타내 었다. 감귤부산물을 급여하지 않은 닭고기로 제조한 프레스 햄(T0)과 급여한 닭고기로 제조한 프레스 햄(T1)의 L*, a* 및 $\mathrm{b}^{*}$ 값은 서로 유의한 차이가 없었다. 식육제품의 색깔은 소비자 들의 구매 욕구를 자극하는 요인으로 발색제로 첨가한 아질산 염이나 질산염이 근육 중의 myoglobin과 화학적 반응을 일으 켜 나타난다[7]. 따라서 감귤부산물을 급여하거나 하지 않은 닭고기를 원료로 하였을 경우 원료육의 색깔에는 영향을 미칠 수도 있겠지만 발색제를 첨가하였을 때 나타나는 발색현상에 는 영향을 미치지 않았다.

Table 2. Chemical composition of chicken press ham (\%)

\begin{tabular}{lrr}
\hline \multicolumn{1}{c}{ Trait } & \multicolumn{1}{c}{$\mathrm{T}^{1)}$} & \multicolumn{1}{c}{$\mathrm{T}^{2)}$} \\
\hline Moisture & $54.1 \pm 0.4^{3)}$ & $53.8 \pm 0.2$ \\
Crude protein & $25.3 \pm 0.5$ & $25.0 \pm 0.2$ \\
Crude fat & $15.8 \pm 0.4$ & $16.2 \pm 0.3$ \\
Crude ash & $4.7 \pm 0.1$ & $4.6 \pm 0.0$ \\
Crude fiber & $0.1 \pm 0.1$ & $0.4 \pm 0.2$
\end{tabular}

${ }^{1)}$ Ham prepared from chicken meat not fed with citrus byproduct.

${ }^{2)}$ Ham prepared from chicken meat fed with citrus byproduct

${ }^{3)}$ Mean \pm S.D.

Table 3. Hunter's color of chicken press ham

\begin{tabular}{crr}
\hline Hunter's color & \multicolumn{1}{c}{$\mathrm{T}^{1)}$} & \multicolumn{1}{c}{$\mathrm{T}^{2)}$} \\
\hline $\mathrm{L}^{*}$-value & $68.9 \pm 5.5^{3)}$ & $69.6 \pm 7.9$ \\
$\mathrm{a}^{*}$-value & $6.8 \pm 0.8$ & $6.2 \pm 0.8$ \\
$\mathrm{~b}^{*}$-value & $13.9 \pm 0.5$ & $13.7 \pm 0.5$ \\
\hline
\end{tabular}

${ }^{1-3)}$ The same as in Table 2.

\section{닭고기 기계적 조직감 및 보수력}

닭고기 프레스 햄의 기계적 조직감 및 보수력을 측정한 결 과는 Table 4 와 같다. 감귤부산물을 급여하지 않은 닭고기로 제조한 프레스 햄(T0) 및 급여한 닭고기로 제조한 프레스 햄 (T1)의 경도(3,193.2 및 3,234.0 dyne $\left./ \mathrm{cm}^{2}\right)$, 탄성 $(90.2 \%$ 및 $90.9 \%)$, 응집성 $(69.0 \%$ 및 $70.0 \%)$, 뭉침성 $(539.1$ 및 $552.2 \mathrm{~kg}$ ), 저작성 $(347.5$ 및 $360.5 \mathrm{~g})$, 전단력 $(5,251.3$ 및 5,280.4 kg) 그리고 보수력 $(31.2 \%$ 및 $31.5 \%)$ 은 유의한 차이가 없어서 감귤부산물 급여가 프레스 햄의 조직감에는 영향을 미치지 않은 것으로 나타났다. 기계적 조직감을 연구한 결과들을 보면 Young 등 [26]은 지방함량에 따라 경도, 응집성 및 저작성 등의 조직감이 달라진다고 하였으며, Song 등[19]은 식육제품의 조직감은 함 유 지방 및 수분, 원료육의 성상, 첨가물의 종류 등에 따라 다르게 나타나며, 가열온도의 차이도 조직감에 영향을 미칠 수 있다고 하였다. 따라서 본 연구의 기계적 조직감이나 보수 력이 처리구간에 차이가 없는 것은 지방의 첨가량 및 종류, 물의 첨가량, 살코기 비율 등이 같았기 때문인 것으로 생각되 며, 이러한 결과는 관능적 조직감에도 영향을 미칠 것으로 사 료된다.

저장 중 닭고기 프레스 햄의 $\mathrm{pH}, \mathrm{VBN}$, TBARS 및 총균 수의 변화

프레스 햄을 4 주일 동안 $4^{\circ} \mathrm{C}$ 에서 냉장하면서 $\mathrm{pH}, \mathrm{VBN}$ 함 량, TBARS값 및 총균수의 변화를 실험한 결과는 Table 5 와 같다. 감귤부산물을 급여하지 않은 닭고기(T0)와 급여한 닭고 기(T1)의 저장 1 주째 $\mathrm{pH}$ 는 6.05로 같았으며, 저장 4 주까지 유 의한 변화를 보이지 않아서 감귤부산물 급여가 프레스 햄의 $\mathrm{pH}$ 에는 영향을 미치지 않았다. 프레스 햄의 $\mathrm{VBN}$ 함량은 저장 1 주째 $\mathrm{T} 0$ 및 $\mathrm{T} 1$ 이 각각 9.2 및 $9.1 \mathrm{mg} \%$ 이던 것이 저장기간이 경과하면서 유의하게 증가하여 저장 4 주째에는 각각 15.1 및 $13.7 \mathrm{mg} \%$ 를 나타내었다 $(\mathrm{p}<0.05)$. T0 및 T1 사이의 VBN함량 은 저장 3 주까지는 차이가 없었으나 저장 4 주째에는 $\mathrm{T} 0$ 가 $\mathrm{T} 1$ 보다 유의하게 높았으며 $(\mathrm{p}<0.05)$, 저장 중 $\mathrm{VBN}$ 함량의 증가속 도는 $\mathrm{T} 1$ 이 $\mathrm{T} 0$ 보다 느리게 증가하는 효과가 있었다. VBN함량 은 단백질 분해물이 세균의 환원작용에 의하여 생성되기 때문 에[2] 세균증식이 $\mathrm{VBN}$ 함량에 영향을 미친다.

Table 4. Textural properties of chicken press ham

\begin{tabular}{lcc}
\hline \multicolumn{1}{c}{ Traits } & $\mathrm{T} 0^{1)}$ & $\mathrm{T}^{2)}$ \\
\hline Hardness (dyne $\left./ \mathrm{cm}^{2}\right)$ & $3,193.2 \pm 79.6^{3)}$ & $3,234.0 \pm 67.2$ \\
Springiness $(\%)$ & $90.2 \pm 0.6$ & $90.9 \pm 1.0$ \\
Cohesiveness $(\%)$ & $69.0 \pm 1.8$ & $70.0 \pm 2.0$ \\
Gumminess $(\mathrm{kg})$ & $539.1 \pm 15.9$ & $552.2 \pm 15.2$ \\
Chewiness $(\mathrm{g})$ & $347.5 \pm 34.3$ & $360.5 \pm 24.8$ \\
Shear force (kg) & $5,251.3 \pm 63.1$ & $5,280.4 \pm 47.4$ \\
Water holding capacity (\%) & $31.2 \pm 2.0$ & $31.5 \pm 0.5$ \\
\hline 1 3) The same as in Table 2. & &
\end{tabular}


Table 5. pH, VBN content, TBARS value and total plate counts of chicken press ham

\begin{tabular}{lccc}
\hline \multicolumn{1}{c}{ Traits } & $\begin{array}{c}\text { Storage } \\
\text { weeks }\end{array}$ & $\mathrm{T} 0^{1)}$ & $\mathrm{T} 1^{2)}$ \\
\hline & 1 & $6.5 \pm 0.1^{\mathrm{3})}$ & $6.5 \pm 0.1$ \\
$\mathrm{pH}$ & 2 & $6.6 \pm 0.1$ & $6.5 \pm 0.1$ \\
& 3 & $6.5 \pm 0.1$ & $6.5 \pm 0.1$ \\
& 4 & $6.5 \pm 0.1$ & $6.5 \pm 0.2$ \\
\hline & 1 & $\left.9.2 \pm 1.6^{\mathrm{d} 4}\right)$ & $9.1 \pm 1.8^{\mathrm{b}}$ \\
VBN(mg\%) & 2 & $12.1 \pm 1.7^{\mathrm{c}}$ & $11.0 \pm 1.8^{\mathrm{b}}$ \\
& 3 & $14.1 \pm 1.4^{\mathrm{ab}}$ & $13.7 \pm 1.0^{\mathrm{a}}$ \\
& 4 & $\left.15.1 \pm 1.6^{\mathrm{aA} 5}\right)$ & $13.7 \pm 0.9^{\mathrm{aB}}$ \\
\hline & 1 & $0.22 \pm 0.02^{\mathrm{d}}$ & $0.19 \pm 0.02^{\mathrm{b}}$ \\
TBARS & 2 & $0.29 \pm 0.04^{\mathrm{cA}}$ & $0.21 \pm 0.03^{\mathrm{bB}}$ \\
(mg maloaldehyde/kg) & 3 & $0.31 \pm 0.06^{\mathrm{bA}}$ & $0.22 \pm 0.01^{\mathrm{bB}}$ \\
& 4 & $0.49 \pm 0.05^{\mathrm{aA}}$ & $0.32 \pm 0.03^{\mathrm{aB}}$ \\
\hline & 1 & $3.97 \pm 0.02^{\mathrm{d}}$ & $3.96 \pm 0.20^{\mathrm{c}}$ \\
Total plate counts & 2 & $4.32 \pm 0.06^{\mathrm{c}}$ & $4.32 \pm 0.03^{\mathrm{b}}$ \\
(Log CFU/g) & 3 & $4.86 \pm 0.06^{\mathrm{b}}$ & $4.66 \pm 0.11^{\mathrm{a}}$ \\
& 4 & $4.96 \pm 0.04^{\mathrm{aA}}$ & $4.72 \pm 0.06^{\mathrm{aB}}$ \\
\hline
\end{tabular}

\footnotetext{
${ }^{1-3)}$ The same as in Table 2.

${ }^{4)}$ Values with different superscripts in the same row are significantly different at $p<0.05$.

${ }^{5)}$ Values with different superscripts in the same column are significantly different at $p<0.05$.
}

한편, 지방산화의 중간물질인 malonaldehyde의 함량을 측 정한 TBARS값은 저장 1 주째 $\mathrm{T} 0$ 및 $\mathrm{T} 1$ 이 각각 0.22 및 0.19 $\mathrm{mg}$ malonaldehyde/ $\mathrm{kg}$ 에서 저장 4 주째 각각 0.49 및 $0.32 \mathrm{mg}$ malonaldehyde $/ \mathrm{kg}$ 으로 유의하게 증가하였다 $(\mathrm{p}<0.05)$. 그러 나 TBARS의 증가는 $\mathrm{T} 0$ 의 경우 저장 2 주째부터 유의하게 증가 하였으나 $\mathrm{T} 1$ 은 저장 5 주째 유의하게 증가하여서 $\mathrm{T} 1$ 이 $\mathrm{T} 0$ 보다 증가하는 속도가 낮았다. Yang 등[23]은 한우에게 감귤부산물 을 급여한 결과 지방산화가 억제되었다고 하였으며, Jung 등 [5]은 감귤부산물을 급여한 토종닭의 항산화력이 우수하다고 하였는데, 이들은 감귤에 함유된 flavonoid류가 항산화작용을 한 결과라고 설명하였다. 본 연구에서 감귤부산물을 급여한 닭고기로 제조한 프레스 햄의 지방산화가 낮은 것은 원료육의 상태가 감귤부산물을 급여하지 않은 닭고기보다 산화의 진행 정도가 적어서 나타난 결과이며, 이것은 프레스 햄으로 제조 한 후 저장 중에도 영향을 미친 것으로 사료된다.

저장 중 프레스 햄의 총균수 실험결과는 저장 1 주째 $\mathrm{T} 0$ 및 $\mathrm{T} 1$ 이 각각 3.97 및 $3.96 \mathrm{Log} \mathrm{CFU} / \mathrm{g}$ 으로 유의한 차이가 없었 다. 그러나 저장 중 총균수는 증가하여 저장 3 주째 $\mathrm{T} 0$ 및 $\mathrm{T} 1$ 이 각각 4.86 및 $4.66 \mathrm{Log} \mathrm{CFU} / \mathrm{g}$, 저장 4 주째 각각 4.96 및 4.72 $\log \mathrm{CFU} / \mathrm{g}$ 으로 저장 기간이 경과하면서 $\mathrm{T} 0$ 가 T1보다 유의하 게 높았다 $(\mathrm{p}<0.05)$. 일반적으로 식육의 총균수 가식범위는 $7.0 \mathrm{Log} \mathrm{CFU} / \mathrm{g}$ 으로 알려져 있으며[15] 본 연구의 프레스 햄은 저장 5 주까지 그 이하를 나타내어 가식권에 있었으며, 감귤부
Table 6. Sensory score of chicken press ham

\begin{tabular}{lll}
\hline \multicolumn{1}{r}{ Trait } & \multicolumn{1}{c}{$\mathrm{T}^{1)}$} & $\mathrm{T}^{2)}$ \\
\hline Aroma & $4.9 \pm 0.5^{3 \mathrm{bb} 4)}$ & $5.7 \pm 0.3^{\mathrm{a}}$ \\
Taste & $5.3 \pm 0.3^{\mathrm{b}}$ & $5.9 \pm 0.3^{\mathrm{a}}$ \\
Texture & $5.6 \pm 0.1$ & $5.8 \pm 0.4$ \\
Juiciness & $5.0 \pm 0.4$ & $5.2 \pm 0.3$ \\
Palatability & $5.1 \pm 0.3^{\mathrm{b}}$ & $5.8 \pm 0.3^{\mathrm{a}}$ \\
\hline
\end{tabular}

${ }^{1 \sim 3)}$ The same as in Table 2.

${ }^{4)}$ Values with different superscripts in the same row are significantly different at $p<0.05$.

산물 급여 닭고기로 제조한 프레스 햄의 선도가 더 우수한 상태였다.

\section{닭고기 프레스 햄의 관능특성}

관능특성은 이화학적 검사나 미생물학적 검사와 같은 객관 적 품질검사와는 달리 인간의 감각기관을 이용하여 보편타당 한 신뢰성 있는 결론을 내리는 주관적인 평가방법이기 때문에 소비자들의 구매욕구와 직접적인 연관이 있어서 중요한 실험 방법 중의 하나이다. Table 6 은 감귤부산물을 급여하지 않은 닭고기로 제조한 프레스 햄과 급여한 닭고기로 제조한 프레스 햄의 관능특성을 나타낸 것이다. 향기, 맛 및 전체적인 기호성 은 T1이 T0보다 유의하게 우수하였다(p<0.05). 그러나 조직감 및 다즙성은 $\mathrm{T} 0$ 및 $\mathrm{T} 1$ 사이에 유의한 차이가 없었다. 이상의 결과들을 종합해 보면 감귤부산물 급여 닭고기로 제조한 프레 스 햄은 VBN함량, TBARS값, 총균수 등의 증가속도가 낮아 신선도를 연장하는데 효과적이었으며, 일부 관능특성이 우수 하기 때문에 육제품의 원료육으로 사용하면 기능성을 가진 제품의 제조가 가능할 것으로 평가된다.

\section{References}

1. Buege, A. J. and S. D. Aust. 1978. Microsomal Lipid Peroxidation. pp. 302-310, In Gleischer, S. and L. Parker (eds.), Methods in Enzymology, Vol. 52, Academic Press Inc., New York

2. Coresopo, F. L, R. Millan, and A. S. Moreno. 1978. Chemical changes during ripening of spanish dry. III. Changes in water soluble N-compounds. A Archivos de Zootechia 27, 105-108.

3. Georgantelis, D., G. Blekas, P. Katikou, I. Ambrosiadis, and D. J. Fletouris. 2007. Effect of rosemary extract, chitosan and $\alpha$-tocopherol on lipid oxidation and colour stability during frozen storage of beef burgers. Meat Sci. 75, 256-264.

4. Jung, I. C., S. J. Kang, J. K. Kim, J. S. Hyon, M. S. Kim, and Y. H. Moon. 2003. Effects of addition of perilla leaf powder and carcass grade on the quality and palatability of pork sausage. J. Korean Soc. Food Sci. Nutr. 32, 350-355.

5. Jung, I. C., J. B. Yang, and Y. H. Moon. 2008. Effects of feed containing citrus byproducts on the physico-chemical characteristics and palatability of Korean native chickens. 
J. East Asian Soc. Dietary Life 18, 524-530.

6. Jung, I. C., D. H. Youn, and Y. H. Moon. Quality and palatability of pork patty containing wine. J. Korean Soc. Food Sci. Nutr. 36, 355-360.

7. Kang, S. J., Y. H. Moon, and I. C. Jung. 2004. Effect of carcass grade and addition of mugwort on the physicochemical properties and palatability of loin ham. J. Life Sci. 14, 239-244.

8. Kim, I. S., S. K. Jin, K. H. Park, K. J. Jeong, D. H. Kim, M. R. Yang, and Y. S. Chung. 2007. Quality characteristics of low-fat sausage containing curcumin extract during cold storage. Korean J. Food Sci. Ani. Resour. 27, 255-261.

9. Korean Food and Drug Administration. 2002. Food Code. Moonyoungsa, Seoul, pp. 217-225.

10. Macarthy, T. L., J. P. Kerry, J. F. Kerry, P. B. Lynch, and D. J. Buckley. 2001. Assessment of the antioxidation potential of natural food and plant extracts in fresh and previously frozen pork patties. Meat Sci. 57, 177-184.

11. Minussi, R. C., M. Rossi, L. Bologna, L. Cordi, D. Rptilio, G. M. Pastore, and N. Duran. 2003. Phenolic compounds and total antioxidant potential of commercial wine. Food Chem 82, 409-416.

12. Montesinos-Herrero, C., M. A. del Río, C. Pastor, O. Brunetti, and L. Palou. 2009. Evaluation of brief potassium sorbate dips to control postharvest Penicillium decay on major citrus species and cultivars. Postharvest Biol. Technol. 52, 117-125.

13. Mytle, N., G. L. Anderson, M. P. Doyle, and M. A. Smith. 2006. Antimicrobial activity of clove oil in inhibiting Listeria monocytogenes on chicken frankfurters. Food Control 17, 102-107.

14. Nam, J. H., H. I. Song, C. K. Park, Y. H. Moon, and I. C. Jung. 2000. Quality characteristics of pork patties prepared with mugwort, pine needle and fatsia leaf extracts. J. Life Sci. 10, 326-332.

15. Nottingham, P. M. 1982. Microbiology of carcass meat, pp.
13, In Brown, M. H. (ed.), Meat Microbiology, Applied Science Publishers Ltd. London.

16. Park, G. L., S. M. Avery, J. L. Byers, and D. B. Nelson. 1983. Identification of bioflavonoids from citrus. Food Technol. 37, 98-105.

17. Park, S. Y. and K. B. Chin. 2007. Evaluation of antioxidant activity in pork patties containing bokbunja (Rubus coreanus) extract. Korean J. Food Sci. Ani. Resour. 27, 432-439.

18. Sallam, K. I., M. Ishiorosh, and K. Samejima. 2004. Antioxidant and antimicrobial effects of garlic in chicken sausage. LWT-Food Sci. Technol. 37, 849-855.

19. Song, H. I., G. I. Moon, Y. H. Moon, and I. C. Jung. 2000. Quality and storage stability of hamburger during low temperature storage. Korean J. Food Sci. Ani. Resour. 20, 72-78.

20. Song, H. I., C. K. Park, J. H. Nam, J. B. Yang, D. S. Kim, Y. H. Moon, and I. C. Jung. 2000. Quality and palatability of beef patty containing gums. J. Korean Soc. Food Sci. Nutr. 31, 261-268.

21. SPSS. 1999. SPSS for windows Rel. 10.05. SPSS Inc., Chicago, USA.

22. Stone, H. and J. L. Sidel. 1985. Sensory evaluation practices. pp. 45. Academic press Inc., New York, USA.

23. Yang, S. J., I. C. Jung, and Y. H. Moon. 2007. Physicochemical properties and sensory characteristics Korean native beef loin fed with citrus byproduct. J. Life Sci. 17, 540-545.

24. Yang, S. J., I. C. Jung, and Y. H. Moon. 2008. Effects of feeding citrus byproduct on nutritional components of Korean native chickens. J. Life Sci. 18, 1369-1376.

25. Youn, D. H., Y. H. Moon, and I. C. Jung. 2007. Changes in quality of pork patty containing red wine cold storage. Korean J. Life Sci. 17, 91-96.

26. Young, L. L., J. M. Garcia, H. S. Lillard, C. E. Lyon, and C. M. Papa. 1991. Fat contents effects on yield, quality, and microbiological characteristics of chicken patties. J. Food SCi. 56, 1527-1528.

\section{초록 : 감귤부산물 급여 닭고기 프레스 Ham의 이화학적 특성 및 기호성}

\section{문윤희 · 정인철 ${ }^{1}$}

(경성대학교 식품생명공학과, ${ }^{1}$ 대구공업대학 식음료조리계열)

본 연구는 감귤부산물을 급여하지 않은 닭고기(T0)와 급여한 닭고기(T1)로 프레스 햄을 제조하고 이화학적 특 성 및 관능특성을 비교하였다. 수분, 조단백질, 조지방, 조회분, 조섬유, $\mathrm{L}^{*}, \mathrm{a}^{*}, \mathrm{~b}^{*}$ 값, 경도, 탄성, 응집성, 뭉침성, 씹힘성, 전단력, 보수력 및 $\mathrm{pH}$ 는 $\mathrm{T} 0$ 및 $\mathrm{T} 1$ 사이에 유의한 차이가 없었다. $\mathrm{VBN}$ 함량은 저장 3 주까지는 $\mathrm{T} 0$ 및 $\mathrm{T} 1$ 사이에 유의한 차이가 없었으나 저장 4 주째에는 $\mathrm{T} 0$ 및 $\mathrm{T} 1$ 이 각각 15.1 및 $13.7 \mathrm{mg} \%$ 로 $\mathrm{T} 1$ 이 유의하게 낮았다(p $<0.05$ ). TBARS값은 저장 2 주까지 $\mathrm{T} 0$ 및 $\mathrm{T} 1$ 사이에 유의한 차이가 없었으나 저장 3 주째에는 $\mathrm{T} 0$ 및 $\mathrm{T} 1$ 이 각각 0.31 및 $0.22 \mathrm{mg}$ malonaldehyde $/ \mathrm{kg}$, 저장 4 주째에는 각각 0.49 및 $0.32 \mathrm{mg}$ malonaldehyde $/ \mathrm{kg}$ 으로 저장기간이 경과하면서 $\mathrm{T} 1$ 이 $\mathrm{T} 0$ 보다 유의하게 낮은 경향이었다 $(\mathrm{p}<0.05)$. 저장 중 총균수는 3 주까지 $\mathrm{T} 0$ 및 $\mathrm{T} 1$ 사이에 유의한 차이가 없었으나 저장 4 주째에는 $\mathrm{T} 0$ 및 $\mathrm{T} 1$ 이 각각 4.96 및 $4.72 \log \mathrm{CFU} / \mathrm{g}$ 으로 $\mathrm{T} 1$ 이 $\mathrm{T} 0$ 보다 유의하게 낮았다(p $<0.05)$. 향기, 맛 및 전체적인 기호성은 $\mathrm{T} 1$ 이 $\mathrm{T} 0$ 보다 유의하게 우수하였지만 $(\mathrm{p}<0.05)$, 조직감 및 다즙성은 $\mathrm{T} 0$ 및 $\mathrm{T} 1$ 사이에 유의한 차이가 없었다. 